tuottavat satoa, mutta eivät välttämättä huomenna vaan pidemmällä aikavälillä.

TAARNA VALTONEN etunimi.sukunimi@oulu.fi

Kirjoittaja on Suomen Akatemian tutkijatohtori Oulun yliopiston Giellagas-instituutissa. Hän toimi Tiina Aallon vastaväittäjänä.

\section{Lähteet}

Harling-Kranck, Gunilla 1990: Namn på åkrar, ängar och hagar. Helsingfors: Svenska litteratursällskapet i Finland.

- - 1975: Paikannimien rakennetyypeistä. Helsinki: Suomalaisen Kirjallisuuden Seura.

Kiviniemi, Eero 199o: Perustietoa paikannimistä. Helsinki: Suomalaisen Kirjallisuuden Seura.

LAITI, IrMA 1996: Ohcejotsis báikenamat: syntávssalaš-semánttalaš luohkkájuohku. - Vesa Guttorm (toim.), Čavčča 1995 sámegiela ja girjjálašvuođa dutkan- ja bagadansymposia: symposiaraporta nr. III s. 21-24. Guovdageaidnu: Sámi instituhtta.

Mallat, Kaija 2007: Naiset rajalla. Kyöpeli, Nainen, Naara(s), Neitsyt, Morsian, Akka ja Ämmä Suomen paikannimissä. Helsinki: Suomalaisen Kirjallisuuden Seura.

SePpäLÄ, Janne 2013: Kulkine.net. Tutkimus epävirallisista kulkineennimistä. www.kulkine.net (4.5.2020).

Zilliacus, KuRT 1972: Nimistötieteellisten synteesien aikaa. - Hannes Sihvo (toim.), Nimikirja s. 360-382. Kalevalaseuran vuosikirja 52. Helsinki: WSOY.

_ 1973: Kulturen och namnskicket. - Kurt Zilliacus (toim.), Synvinklar på ortnamn s. 7-24. Skrifter utgivna av Svenska Litteratursällskapet i Finland nr 454. Meddelandet från Folkkultursarkivet 1. Helsingfors: Svenska Litteratursällskapet i Finland.

\title{
Kielioppi kerrosten ja kytkentöjen verkostona
}

Urpo Nikanne: Conceptual semantics. A micro-modular approach. Constructional Approaches to Language 23. Amsterdam: John Benjamins Publishing Company 2018. xvi + 281 s. ISBN 978-90-272-0117-1.

John Benjamins -kustantamon vuonna 2004 aloittamassa sarjassa Constructional Approaches to Language on tähän mennessä julkaistu 27 nidettä konstruktiokieliopin alalta. Urpo Nikanteen teos on sarjan ensimmäinen suomalaisen lingvistin kirjoittama monografia. Teos on huomattava siksikin, että sen teoreettisena kehyksenä on konseptuaalinen semantiikka (jatkossa KS), joka ei ole varsinaisesti konstruktiokieliopin mukainen teoria.
KS on alkuaan Ray Jackendoffin 1970-luvulla kehittelemä kielenkuvausmalli, jonka perustalta Nikanne esittää oman Tiernet-malliksi nimeämänsä version. Syitä teoksen julkaisemiselle Benjaminsin sarjassa lienee ainakin kaksi: Ensinnä Tiernet-malli esittää representaation kielen kognitiivisesta jäsentymisestä semantiikan ilmiöihin keskittyen. Toiseksi mallin konstruktiokäsitys on suppeampi kuin konstruktiokieliopissa, kuten edempänä havainnollistan. Tämä haastaa pohtimaan sekä konstruktion käsitettä että kielenkuvausmallien perusteita yleensä. Tiernet ei ole kuvaus mistään yksittäiskielestä, vaan kyse on yleismallista. Esimerkkiaineistoa tekijä esittää englannista ja suomesta. 
Nikanne on pitkän linjan KS-tutkija (esim. 1989, 1990, 1992), ja Tiernet-malli on vuosien kehittelyn tulos. Nikanteen ohjauksessa on Suomessa syntynyt kolme KS:n alaan kuuluvaa väitöskirjaa (Pörn 2004; Paulsen 2011; Petrova 2011). Lisäksi hän on ollut mukana tutkimassa suomen paikallissijoja KS:n kehyksessä (ks. Leino, Helasvuo, Lauerma, Nikanne \& Onikki 1990).

\section{Teoksen rakenne}

Teos koostuu neljästä osasta, jotka jakaantuvat sisällöltään seuraavasti: perusteet (luvut 1-2), semantiikka (luvut 3-5), syntaksi (luvut 6-8) ja johtopäätökset (luku 9). Näitä edeltää tiivis johdanto (s. $\mathrm{xv}-\mathrm{xvi}$ ), jossa teoksen taustaa avataan. Kuvausmalli lähtee generatiivisesta perinteestä ja erityisesti jackendoffilaisesta KS:sta, mutta se pyrkii tarjoamaan kielijärjestelmän jäsentymisestä uudenlaisen kuvan. Kirjan lopussa on lyhenneluettelo, lähdeluettelo sekä hakemistot konstruktioista ja asiasanoista.

Teoksen kokonaisrakenne on tasapainoinen, vaikka perusteiden (30 sivua) ja päätelmien ( 3 sivua) olisi suonut avaavan taustoja enemmän. Teos keskittyy kuvausmallin käytännölliseen esittelyyn ja kielen formaaliin kuvaamiseen. Semantiikkaa käsittelevä osa kattaa vajaat sata sivua ja syntaksia käsittelevä noin 125 sivua. Esittelen seuraavassa teoksen oman luentani pohjalta.

\section{Teorian perusteita}

KS:n tutkimuskohteena on ihmiskieli osana mieltä. Tämä on yhdistävä piirre kaikissa kielen ja kognition suhdetta pohtivissa kielentutkimuksen suuntauksissa, esimerkiksi generatiivisessa (kuten KS:ssä) ja kognitiivisessa kielentutkimuksessa (jatkossa KK).

1. Kiitän Geda Paulsenia konseptuaalista semantiikkaa koskevasta keskustelustamme.
KS:n ja KK:n välillä on kuitenkin myös selviä eroja, vaikka Nikanne ei seuraavia vertailuja itse esitäkään:

- Generatiivisten lähtökohtiensa myötä KS esittää taustaoletuksinaan, että ydinkielioppi on kuvattavissa yleisinä sääntöinä tai sääntömuotoisina periaatteina. KK:ssa säännöt on korvattu skeemoilla ja konstruktioilla.

- KS:ssa yksittäiskielten oletetaan olevan ainakin osin universaalikieliopin (universal grammar, UG) johdannaisia. KK:ssa ei ole oletusta UG:sta.

- KS:ssa mieli ja kieli ovat modulaarisia eli osasysteemeistä koostuvia; KK:ssa on antimodulaarinen käsitys.

- KS:ssa kielioppiin kohdistuu erilaisia rajoitteita, jotka periytyvät muusta kognitiosta. KK:ssa ei ole tällaista oletusta.

- Ydinkieliopin olettamisesta KS:ssa seuraa, että kielessä olisi myös periferia, jonne kielen epäsäännöllisyydet (idiomit ja konstruktiot) sijoittuvat. KK näkee kielen yhtenäisenä konventionaalisten yksiköiden kokoelmana. (S. 5-11.)

Siitä olen Nikanteen kanssa eri mieltä, että vain KS tavoittelisi formaalia teoriaa (s. 6). Kyllähän myös KK:n suuntauksissa käytetään formalismeja (esim. Langacker 1987; Goldberg 1995; Boas \& Sag toim. 2012). Nikanteen käsityksessä formalistisuus tulee kai ymmärtää niiden taustaoletusten ja metodologisten periaatteiden valossa, joita KS edustaa. Ehkä näkemystä olisi voinut avata lisää. Lisäksi Nikanne esittää KS:n kuvauksen olevan systeemiperustainen ja muoto-orientoitunut. Lukija saattaa miettiä, mitä muotoperustaisuus tarkoittaa KS:ssa, joka on ennen muuta semanttinen kuvausmalli kielestä.

Metodologian osalta teos jättää avoimeksi, mistä kuvauksen kielenaines on 
peräisin ja mitä kieltä malli kuvaa. Nikanne ei sitä selvästi sano, mutta valtaosa esimerkeistä on tutkijan kielitajun varaisia ja hyvin usein kirjoitetun yleiskielen mukaisia. ${ }^{2}$ Silti Nikanteen kuvaus ei yleisenä mallina koske yksinomaan esimerkiksi suomen kirjoitettua yleiskieltä. Teoksen alussa olisi ollut hyvä pohtia kuvattavan kielen suhdetta kuvausmallin yleistettävyyteen.

Nikanteen mallissa metodologiset periaatteet ja formaalis-tekniset ratkaisut asettuvat osin päällekkäin (s. 5). Luvussa 2 näistä tarjotaan havainnollinen yleiskuva. KS:n keskeisisin piirre on modulaarisuus. Piirre on generatiivisen kieliopin perua (s. 17-21). Mallivaikutusta on myös 1970ja 1980-lukujen ei-lineaarisella fonologialla (esim. McCarthy 1982), jossa kuvaus rakentuu toisiinsa kytkeytyvistä osasysteemeistä (tavurakenne, paino, tooni jne.) eli kerroksista (tier) (s. 22-23). Kerroksia ei johdeta toisistaan, vaan niillä on omat säännöstönsä. Moduulien välisistä kytkennöistä (linking) muodostuu verkosto (net). Tähän perustuu Nikanteen mallin nimitys Tiernet.

Kerrokset pyritään esittämään mahdollisimman yksinkertaisina mikromoduuleina. Moduuleja on kahdentyyppisiä, primaarisia ja symbolisia. Edellisiä ovat esimerkiksi funktioketju, temaattiset piirteet ja argumenttitaso (ks. kuviota 1 tässä arviossa). Moduulit muodostavat omia kerroksiaan, joilla on omat primitiivit ja yhdistymisperiaatteet sekä primaarimoduulien keskinäiset kytkentäsäännöt. Jälkimmäiset kohdistuvat leksikkoon, morfologiaan ja konstruktioihin. Kytkentäsäännöt ovat fragmentteja primaarimoduulien muodostamista rakenteista, joilla on sekä kielellinen muoto että merkitys. Huomattavaa on, että symboliset moduulit voi hahmottaa kieliopin perinteisinä representaatiotasoina (erit. leksikko ja morfologia). Primaarimoduu-

2. Korpusesimerkeissä on lähdeviite. lit ovat tämän tarkastelutason "alapuolelle" sijoittuvia systeemejä. Ne kuvaavat käsiterakenteen perusosia ikään kuin ennen kielellistä muotoa, mistä nimitys konseptuaalinen semantiikka. Nikanteen kieliopille hahmottelema kokonaisarkkitehtuuri havainnollistuu hyvin luvun 2 kuvioissa (ks. s. 24, 27-28). Primaarimoduulien sisäistä ja keskinäistä yhdistelyä ohjaavat konstituenssi eli sisältyminen, valinta eli vaikutusalaan ottaminen, dependenssi eli riippuvuus, lineaarinen järjestys ja hierarkia eli mikromoduulien yhdistämisen järjestystä koskevat säännöt (s. 28-31).

\section{"Semantiikka"}

Moni kielenkuvauksen nykymalli on semanttinen (esim. kognitiivinen kielioppi, kehyssemantiikka, eräät konstruktiokieliopin variaatiot). Tämä on ollut vastareaktio generatiivisen perinteen syntaksikeskeisyydelle. KS:ssa semantiikalla tavoitellaan konseptuaalisen rakenteen kerroksisuutta, jota Nikanne kuvaa teoksensa luvuissa $3-5 .{ }^{3}$

Luvussa 3 kuvataan primaaritason moduuleja. Näitä ovat muun muassa funktioeli f-ketju ( $f$-chain), temaattisten piirteiden taso (thematic features), argumenttitaso (argument level) ja tekokerros (action tier). Näistä neljästä kerroksesta muodostuu Nikanteen kuvaus argumenttirakenteesta. Jotta Tiernet-mallista voisi saada käsityksen, havainnollistan seuraavaksi kutakin näistä moduuleista ja niiden keskinäisistä kytkennöistä esittämällä

3. Semantiikka koodimerkityksenä ilmenee symbolisten moduulien rakenteissa (esim. sanan, morfeemin tai konstruktion merkitys). Puhuessaan lainausmerkeissä "semantiikasta" ja "syntaksista" Nikanne (s. 32) korostaa perinteisen syntaksin ja semantiikan eron keinotekoisuutta ja toisaalta näiden tasojen käymättömyyttä KS:ssa, jossa kuvausrepresentaation perusteet sijoittuvat perinteisten kuvaustasojen "alapuolelle", käsiterakenteeseen, vaiheeseen ennen kielellistä semantiikkaa. 
kuviossa 1 formaalistuksen lauseesta Keijo nukuttaa lasta illasta yöhön.

Tilannetta kuvaavan käsiterakenteen ydinkerros on kolmen vyöhykkeen f-ketju. Sen hyvämuotoinen skeema on $\mathrm{f}_{3}{ }^{*} \rightarrow \mathrm{f}_{2} \rightarrow \mathrm{f}_{1}{ }^{*}$. Siinä $\mathrm{f}_{3}$ on kausatiivinen tai inkoatiivinen, $f_{2}$ ei-kausatiivinen ja $f_{1}$ paikka- tai väylävyöhyke. Asteriski kertoo, että kyseisiä funktioita voi olla yksi, useampia tai ei yhtään. Näin $f_{3}: 1 l a$ on laajin vaikutusala muihin funktioihin; se voi valita eniten vyöhykkeitä ( $f_{3}: n$ tai $\left.f_{2}: n\right)$ ja niiden funktioita. Valinta osoitetaan nuolilla. Kuviossa $1 \mathrm{f}_{3} \rightarrow \mathrm{f}_{3}$ tarkoittaa verbin nukuttaa (onnistunutta) kausatiivisuutta. ${ }^{4}$ Kuitenkin $\mathrm{f}_{2}$ on käsitteellisesti välttämätön osa kaikkien hyvämuotoisten tilanteiden käsiterakennetta: kaikissa tilanteissa ei ole ilmi käyvää kausatiivisuutta $\left(f_{3}\right)$ tai paikkaa ja väylää $\left(f_{1}\right)$, esimerkiksi Keijo syö (f2). F2 voi valita yhden tai useamman $\mathrm{f}_{1}: \mathrm{n}$, esim. Keijo nukkuu illasta aamuun ( $\mathrm{f}_{2} \rightarrow \mathrm{f}_{1} \mathrm{ja} \mathrm{f}_{1}$ ). (Ks. s. 44.)

4. Kuviossa 1 olen asettanut f-ketjun funktiot f1 lineaarisesti eri kerrosten erillisyyttä havainnollistaakseni. Nikanteen esitystapa on erilainen (esim. s. 61-62).
Nikanne käyttää funktioketjun vyöhykkeiden lyhenteitä läpi kirjan. Vaikka vyöhykkeiden perusfunktiot ovat malliin tottumattomallekin lukijalle esittelyn jälkeen selvät, käytäntö saattaa näyttää käsiterakenteen semantiikkaa typistävältä. Jos jackendoffilaiset merkinnät (CAUSE, BE ym.) olisivat systemaattisesti käytössä, niin mallin semanttinen ydin ja sen kytkeytyminen muihin tasoihin olisi formalismissa eksplisiittisempi (ks. Paulsen 2011). Samalla f-ketjun eri funktiotyyppien variaatioilla voisi havainnollistaa hyvä- ja huonomuotoisten käsiterakenteiden yleisimpiä tyyppejä. Tiernet-mallin fragmentit edustavat Jackendoffin (1990) funktioita, mikä tekee mallista analyyttisemman mutta samalla vaivalloisemmin lähestyttävän. $\mathrm{Ku}$ viossa 1 katkoviivalaatikon sisällä oleva käsiterakenteen fragmentti tai piirrekompleksi kuvaa onnistunutta kausatiivisuutta (CAUSE, CS+). Samalla periaatteella edustuvat myös muut f-ketjun funktiot (ks. alalukua 3.4.7).

Argumenttitaso on oma kerroksensa. Sillä on vain yksi primitiivi (Arg). Fketjun funktiot valitsevat argumentit (ku-

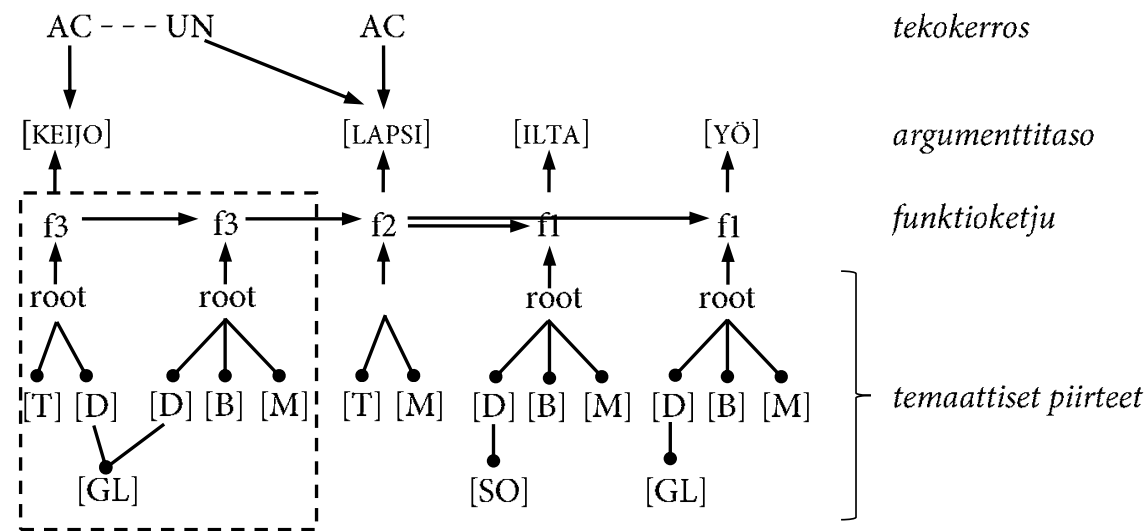

Kuvio 1.

Osa ilmauksen Keijo nukuttaa lasta illasta yöhön käsiterakennetta eli semantiikkaa Tiernet-mallin mukaan kuvattuna. 
vio 1, nuolet ylöspäin, ks. valintasäännöt s. 70). Usein argumenttien nimityksinä käytetään kielioppikuvauksissa abstrakteja semanttisia rooleja, mutta Nikanteen malliin ne eivät sellaisinaan kuulu, vaan argumentteja ovat kielellisen ilmauksen nimettyjen olioiden käsitteet (kuviossa 1 [KEIJO], [LAPSI] jne.). Näin malli eroaa muun muassa useista konstruktiokieliopin variaatioista. Jonkinlaiset protoargumentit sisältyvät implisiittisesti jo fketjuun: f3:ssa Aiheuttaja, f2:ssa Teema ja f1:ssä Tausta (s. 45). Kun mallissa kytketään argumenttikerrokseen kielellisen ilmauksen nimetyt oliot ([KEIJO], [LAPSI] jne.), kytkentä kertoo, mitkä ovat kielellisen ilmauksen käsiterakenteen argumentit, mutta se ei kerro suoraan näiden rooleja tuntematta f-ketjuun sisältyvää implisiittistä tietoa edellä kuvatuista protoargumenteista. Ehkä argumenttikerroksen primitiivien kieleen tai kerrosten väliseen kytkentään saisi näkyville välikategorioina joko perinteisiä semanttisia rooleja (AgENTti, PATiEntTi yms.) tai tilannekohtaisia osallistujarooleja (nukuttaja, nukkuja yms.). Nekin selventäisivät kuvausmallin ytimen semantiikkaa. (Ks. Paulsen 2011: 189-195.)

Funktioketjun alapuolella on temaattisten piirteiden hierarkia (s. 46). Se koostuu piirteistä, jotka muodostavat konstituentteja (pallopäiset viivat) fketjun funktioiden mukaan. Piirrekimpun (feature set) kokoaa juuri (root), joka valitsee f-ketjun funktion (nuoli ylöspäin). Piirteitä on toistakymmentä, esimerkiksi [T] (time-related, tilanteella on aikarakenne), [M] (monadic, rajoitus jossa $\mathrm{f}$ voi valita vain yhden Argprimitiivin), [D] (directed, tapahtumalla on suunta, esim. GL = GOAL 'kohde' ja SO = SOURCE 'lähde') ja [B] (bounded, väylän tai kausatiivisuuden rajautuvuus). Jotkin niistä ovat vyöhykekohtaisia. Valtaosa piirteistä koskee väylää, suuntaisuutta ja paikankuvausta yleisemmin (ks. s. 4756).
Argumenttikerrokseen kytkeytyy tekokerros, jossa on kaksi primitiiviä: AC (actor 'tekijä') ja UN (undergoer 'läpikävijä). AC on kuvatun tilanteen aktiivinen osallistuja, UN passiivinen. Molemmat valitsevat argumenttinsa argumenttitasolta (ks. kuviota 1). Toistensa suhteen ne ovat itsenäisiä. Ne eivät valitse toisiaan, mutta AC dominoi käsitteellisesti UN-primitiiviä (s. 74). Kuviossa 1 merkintä $A C-U N$ tarkoittaa sitä, että AC ja UN kuuluvat samaan tekoketjuun: [KEIJO] on kausatiivisuuden suhteen AC ja [LAPSI] vastaavasti UN. Argumenttiin [LAPSI] kytkeytyvä AC muodostaa oman tekoketjunsa; deverbaalin nukutta- (f 3 ) kanta on nukku- (f2), jonka AC [LAPSI] on. Tekokerroksen jäsentyminen viittaa leksikkoon. Tekokerroksen erottaminen omaksi moduulikseen perustuu siihen, että AC ja UN eivät riipu muiden kerrosten roolimaisista primitiiveistä (s. 72). Perinteiset semanttiset roolit näkyvät ripottuvan Tiernet-kuvauksessa eri primaareihin mikromoduuleihin. Toisin sanoen argumenttirakenne jakautuu neljään mikromoduuliin.

Tiernet-kuvauksen ytimen muodostaa f-ketju eli argumenttitaso, johon kytkeytyvät tekokerros ja temaattiset piirteet. Ne muodostavat kiinteän itsenäisten mikromoduulien klusterin ja edustavat tilannetta kuvaavan käsiterakenteen ei-kielellistä, "propositionaalista" sisältöä. Tähän käsiterakenteen ytimeen kytkeytyvät myös temporaalinen rakenne (luku 4; ks. myös Nikanne 1997) sekä semanttinen kenttä ja modaalikerros (luku 5).

\section{"Syntaksi"}

Edellä olen havainnollistanut Tiernetmallin primaarimoduuleja. Kirjan kolmas osa käsittelee syntaksia. Lukuja 6-8 yhdistää Tiernet-mallin kannalta erityisesti se, että käsiteltävät ilmiöt - leksikko, erilaiset konstruktiot ja morfologia - koskevat symbolisia moduuleja. Niillä 
ei ole Nikanteen (s. 135) mukaan omia primitiivejään, vaan ne ovat fragmentteja primaaristen moduulien ja kytkösten erilaisista kombinaatioista. Ne ovat siis mikromoduulien verkostoja. Kirjan pääosien otsikoiksi olisivat ehkä sopineetkin paremmin "Primaariset moduulit" ja "Symboliset moduulit". Semantiikan ja syntaksin olisi voinut panna sulkuihin.

Perusperiaatteet säilyvät samoina, vaikka symbolisen moduulin rakenteilla voi olla myös erikoispiirteitä, jotka eivät nouse primaarisen moduulin periaatteista. Esimerkiksi leksikaalisia yksiköitä voidaan yhdistää (unification, merging) keskenään joidenkin jaettujen piirteiden osalta (esim. englannin sanojen go ja into temaattiset piirteet [D [GL]], s. 142-144).

Luvussa 6 kuvataan leksikkoa ja leksikaalisten yksiköiden yhdistämistä yksinkertaisiksi lauseiksi. Leksikko on oma symbolinen moduulinsa (s. 26), ja lekseemit ovat informaatiopakkautumia (s. 136-138). Huomiota kiinnittää Nikanteen (s. 140) väite, että taivutusmuodot ovat keskenään vuorovaikutuksessa "horisontaalisesti" samalla tasolla viittaamatta leksikkoon. Näin esimerkiksi kongruenssi tulisi sanojen välisinä suhteina näkyväksi juuri taivutusmuodoissa (esim. pienellä lapsella). Johdokset taas kuuluisivat yksinomaan leksikkoon. Kuitenkin myös yksittäiset taivutusmuodot viittaavat aina kokonaisiin taivutusparadigmoihin, niiden keskinäisiin yhteyksiin, vartalo- ja sija-allomorfiaan sekä (morfologisiin) sanatyyppeihin. Nämä voi nähdä myös syntaksin ulkopuolelta, leksikon jäsentäjinä (Paunonen 1976). Samoin johtimillakin on usein syntaktisia seuraamuksia esimerkiksi verbijohdoksissa (esim. Kangasmaa-Minn 1982). Herääkin kysymys, missä määrin moduulien erillisyys on ennen kaikkea kuvausesteettinen asia.

Käsiterakenteiden lekseemejä edustavat osat kytkeytyvät syntaksiin argumenttikerroksen kytkeytyessä DA-kerroksen (direct argument) kautta GF-kerrokseen (grammatical function), joka kytkeytyy edelleen NP:ihin. DA tarkoittaa leksikaalisesti määräytyneitä loogista subjektia (DA1) ja objektia (DA2); GF-kerros käsittää kieliopillisen subjektin (SUBJ) ja objektin (OBJ). Esimerkiksi lauseen Keijo nukuttaa lasta linkityskuvaus on [KEIJO] $\leftarrow \mathrm{DA} 1 \rightarrow \mathrm{SUBJ} \rightarrow\left[_{\mathrm{NP}}\right.$ Keijo] ja [LAPSI] $\leftarrow \mathrm{DA} 2 \rightarrow \mathrm{OBJ} \rightarrow\left[\left[_{\mathrm{Np}}\right.\right.$ lasta $\left.]\right)$. Passiivissa Lasta nukutetaan linkitys on objektissa sama, mutta subjektia ei rakenteessa ole (ARB 'arbitraarinen'): $[\mathrm{ARB}] \leftarrow \mathrm{DA} 1$ $\rightarrow$ SUBJ $\rightarrow$ [ ]. (Ks. esim. s. 151.) Näistä lähtökohdista Nikanne kuvaa luvussa 6 havainnollisesti esimerkiksi erilaisten deverbaalisten ja denominaalisten verbien varaan rakentuvien lauseiden syntaksia.

Koska DA-kerros on leksikaalisesti määräytynyt, syntaksia sisältyy myös leksikaaliseen moduuliin. Kysymys moduulien erillisyydestä voidaan toistaa. Huomattavaa on se, että argumenttien ja kieliopillisten funktioiden kytkentää koskeva linkitys rajautuu lähinnä päälauseenjäseniin. Esimerkiksi ditransitiivirakenteiden obliikvit (esim. Keijo antaa lapselle tutin) eivät kuvauksessa ilmene. Samoin vaikkapa syntaktiset vaihtelut, kuten Keijo lastaa kollit lavalle ja Keijo lastaa lavan kolleilla, jäävät mielenkiintoisiksi tulevaisuuden tutkimuskohteiksi. Vaikka Nikanteen tarjoama kuvaus onkin tarkoitettu perusperiaatteiden esitykseksi (s. 147), argumentti-adjunkti-jako olisi ollut tärkeä käsiteanalyyttinen polku.

Luvussa 7 kuvataan infinitiivikomplementin saavia verbejä. Näitä ovat kausatiiviverbit (esim. Keijo laittaa lapsen nukkumaan), suunnittelua, päättämistä ja haluamista kuvaavat verbit (esim. Keijo päättää mennä kotiin) ja modaaliverbit (esim. Keijon pitää mennä nukkumaan). Lisäksi kuvataan alistuskonjunktioilla ja relatiivipronomineilla muodostettavia sivulauseita (esim. menen kotiin, koska on myöhä; hän on mies, jolle ei koskaan tapahdu mitään). 
Nikanne nimeää kuvattavista ilmiöistä monet konstruktioiksi (esim. modaaliverbit s. 188; on mentävä -rakenne s. 189; on hyvä varmaa, että S -rakenne s. 199206; omistusrakenne s. 168). Hän tarkoittaa konstruktiolla sellaisia ilmauksia, joiden käsiterakenteessa on idiosynkraattisia piirteitä (esim. linkitystyyppejä), jotka eivät selity mallin yleisten periaatteiden pohjalta. Tämä käsitys muistuttaa konstruktiokieliopin varhaista idiomaattisuutta koskevaa tutkimusta (esim. Fillmore, Kay \& O'Connor 1988). Systemaattista vertailua konstruktiokielioppiin tai sen konstruktio-käsitteeseen ei teoksessa kuitenkaan esitetä.

Erityisesti erilaisten adjunktien konstruktioluonne jäi askarruttamaan. Miten esimerkiksi suomen adessiivimuotoinen

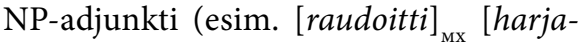
teräksellä] $\left.{ }_{\mathrm{AD}}\right)$ on ymmärrettävä konstruktiona (ks. s. 158): matriisilauseen (MX) ja adjunktin (ADJ) muodostamana kokonaisuutena, kahden erillisen konstruktion kombinaationa vai adjunktirakenteena, joka on oma konstruktionsa (vrt. Hamunen 2019: luku 3.1)? Adjunkteina toimivat sivulauseet (s. 206-211) kuvataan alistuskonjunktion leksikaalisessa rakenteessa, jossa niiden semanttisen suhteen luonne matriisirakenteeseen käy ilmi. Suomen runsaat infinitiivirakenteet (esim. kävellessään, kävelemällä) toimivat adjunkteina myös samankaltaisissa käytöissä (vrt. lauseenvastikkeen käsite), mutta lukuun ottamatta temporaalisen kerroksen tulkintaa (s. 100-102) Nikanne ei esitä niistä kuvausta. Ovatkohan esimerkiksi suomen tavan ja keinon infinitiivit yhä KS:ssa avoimia kuvausongelmia (ks. Lauerma 1990: 277-278; myös Hamunen 2019: luku 3)?

Luvussa 8 esitellään finiittirakenteen jäsentymistä ja sanajärjestystä. Finiittisyys jaetaan finiittisyyspiirteisiin, kuten lekseemi (V), partisiippisuus (Ptc), tempus ja modus (T, M) ja persoonataivutus (AgrS). Piirteet jakautuvat kah- teen eri kerrokseen, nimittäin finiittilauseen morfologisiin (AgrS, T, Ptc ja Pass[iivi]) ja leksikaalisiin (Neg[aatio], Aux 'apuverbi', V) kategorioihin (s. 221). Pakollisia osia suomen finiittirakenteessa ovat AgrS, T ja V (s. 225, esim. [sö-i-n] v-т-AGRS $)$. Epäselväksi jää tapaluokan (M) asema. Kuten temaattisten piirteiden juuret (ks. kuviota 1) myös finiittisyyspiirteet asettuvat oman juurensa ( $\mathrm{m}$-root) alle konstituenssirakenteeksi. Juuri valikoi ensin finiittilauseen morfologiset piirteet, jotka valikoivat leksikaaliset piirteet (s. 223). Nikanne tarjoaa lukuisia esimerkkejä erilaisten finiittirakenteiden jäsentymisestä (s. 225-232).

Huomiota kiinnittää finiittisyyspiirteiden jäsentymisessä se, että Nikanne näkyy hyväksyvän nollamorfeemin. Sivujen 223-224 kuvioissa piirteet aktiivi, yksikkö (luku) ja preesens (tempus) eivät saa morfologista merkintää. Toisaalta tapaluokkiin ei ole sisällytetty nollamorfeemina indikatiivia.

Myös sanajärjestys ja informaatiorakenne esitetään omina kerroksinaan. Sanajärjestys kuvaa asymmetristä ja suuntaista sanojen lineaarista asemaa (O-1-23-4...), jossa kiinteitä paikkoja pitävät AgrS (3) sekä topiikki (2) ja fokus (0). Luvussa 8.4 Nikanne havainnollistaa näiden kerrosten periaatteita sananlaskuaineiston avulla. Aineisto on oivallisesti valittu, sillä se on varioivaa korpusainesta, jonka variaatio on kuitenkin siten rajallista, että minimipareja on mahdollista löytää. Näin haastavaan aiheeseen saadaan vankka empiirinen ote.

\section{Lopuksi}

Nikanteen esittämä mikromodulaarinen Tiernet-malli on kuin räjäytyskuva kielen järjestelmästä. Kun kielioppi puretaan osiinsa, jotka pääsääntöisesti motivoituvat kielen rakenteista, on mallilla nähdäkseni tässä mielessä empiirinen perusta. Mallin yksiköt (primitiivit) edustavat osasystee- 
mien osia, ja niiden erilaiset sääntöperustaiset kytkennät (linkitys) kuvaavat osien liittymistä toisiinsa. Näin muodostuu kuvaus kieliopin kokonaisuudesta.

Kirjan tiiviissä päätösluvussa $9 \mathrm{Ni}$ kanne vielä kertaa kuvausmallinsa strukturalistisen luonteen ja toteaa, että kyse ei ole psykolingvistisestä prosessointimallista ja että mallia sopisi koettaa myös muiden kielten kuvaukseen. Päätännässä olisi voinut vielä käsitellä erityisesti linkityksen periaatteita, joiden tutkimista kirjoittaja itsekin pitää tärkeänä (s. 266; ks. myös s. 32, 81). Eri moduulit ovat usein ymmärrettävissä perinteisen kieliopin avulla, mutta sitä, mikä linkittyy mihinkin, millä linkkityypillä ja miksi, olisi hyvä avata lisää. Milloin jokin ilmiö on oma moduulinsa, ja miten päätetään, mihin ja miten sen primitiivit linkittyvät? Miten irrallisia ja itsenäisiä moduulit lopulta ovat? Myös adjunktien kuvaus ansaitsisi päästä kielioppimallien ikiaikaiselta katvealueelta.

Lopussa teos kurottautuu ihmismielen käsitteenmuodostuksesta ihmisen ymmärtämiseen (s. 266). Tässä olisi voinut yleisemmälläkin tasolla pohtia sitä, mikä on erilaisten kielenkuvausmallien relevanssi kielentutkimuksessa ja ihmiskielen ymmärtämisessä. Samoin vuoropuhelua muiden suuntausten kanssa olisi saanut olla enemmän (vrt. s. 8o).

Toimitustyön jälkeen kirjaan on jäänyt melko paljon huolimattomuusvirheitä. Kirjoitusvirheitä on toisinaan samalla sivulla useita (esim. s. 62), monesti esimerkkien kielenaines on kursivoimatta (esim. s. 91), ja toisinaan esimerkkien numerointi ei täsmää (esim. s. 127). Glossauksessa on sellainen systemaattinen puute, että glossiriveillä on käytetty asianmukaista morfeemien erottelua, mutta itse kielenaineksessa tämä ei näy (esim. s. 139 syöminen eat-MINEN). Erityisesti suomea tuntemattomalle lukijalle systemaattinen glossaaminen on tarpeen. Lyhenneluettelossa (s. 269-270) huomiota kiinnittää se, että kaikkia glossauksissa käytettyjä lyhenteitä ei ole listattu (esim. AGPTC, QCL, Mx). Kuvausmalliin tutustuvalle olisi hyötyä, jos kirjassa käytettyä merkintäkonventiota esiteltäisiin erikseen kootusti ja tiivistetysti (vrt. esim. Sag 2012: 177-189).

Lukijan kannalta hankalin virhetyyppi koskee merkintätapoja. Jos tekninen merkintä ei ole yhtenäistä (esim. s. 181: $D A$ vai $d a$; s. 94 kuvio: [S] vai $[s], p$ vai $P$ ), lukija saattaa pohtia, onko kyseessä lapsus vai mallin tulkinnan kannalta relevantti mutta selittämättä jäänyt formaalistus. Joitakuita suoranaisia virheitäkin kuvauksissa on (esim. s. 228: COND po. IND; s. 231: COND - TENSE po. COND $M O O D)$. Havaitakseni yhdessä formaalistuksessa malli ja leipätekstin selostus eivät kohtaa (s. 172 taulukon 6.1 alempi oikeanpuoleinen kuva).

Teoria on leikki, ja tiede tarvitsee leikkiä. Kielimallit eivät kuitenkaan ole mielikuvitusleikkiä, vaan ne tavoittelevat kuvaa kielisysteemistä. Luonnollisen kielen kokonaisuuteen kuuluvat erottamattomasti sekä erilaiset säännönmukaisuudet ja vakiintumat (systeemi resurssina) että kielellinen käyttäytyminen (resurssien käyttö). Molemmat ovat toistensa edellytyksiä. Siksi onkin kielentutkimuksen kokonaisuuden kannalta hyvä, että on joitakuita, jotka kuvaavat kieltä myös kielisysteemin kannalta. Hyvä olisi sekin, että kielentutkija, joka tavoittelee kielen kuvaamista toisenlaisesta näkökulmasta, tutustuisi Nikanteen kirjaan.

MARKuS HAMUNEN etunimi.sukunimi@helsinki.fi

Kirjoittaja on suomen kielen ja viestinnän lehtori (ma.)

Kaakkois-Suomen ammattikorkeakoulussa.

\section{Lähteet}

\author{
Boas, Hans C. - Sag, Ivan A. (toim.) \\ 2012: Sign-based construction grammar.
}


CSLI Lecture Notes 193. Stanford, CA: Center for the Study of Language and Information.

Fillmore, Charles - Kay, Paul O'Connor, Mary Catherine 1988: Regularity and idiomaticity in grammatical constructions. The case of let alone. - Language 64 s. 501-538.

Goldberg, Adele E. 1995: Constructions. A construction grammar approach to argument structure. Chicago, IL: The University of Chicago Press.

Hamunen, Markus 2019: Tavattomat infinitiivit. Eräiden myötätapahtumisen infinitiivirakenteiden konstruktiokielioppia suomen murteissa. Helsinki: Helsingin yliopisto. http://urn.fi/ URN:ISBN:978-951-51-5203-9.

JACKENDOFF, RAY 1990: Semantic structures. Cambridge, MA: MIT Press.

KangasmaA-Minn, Eeva 1982: Derivaatiokielioppia I. Verbijohdokset. - Sananjalka 24 s. 43-64.

Langacker, Ronald W. 1987: Foundations of cognitive grammar. Volume I. Theoretical prerequisites. Stanford, CA: Stanford University Press.

Lauerma, Petri 1990: Avoimia kuvausongelmia. - Pentti Leino, Marja-Liisa Helasvuo, Petri Lauerma, Urpo Nikanne \& Tiina Onikki (toim.), Suomen kielen paikallissijat konseptuaalisessa semantiikassa s. 261-281. Kieli 5. Helsinki: Helsingin yliopiston suomen kielen laitos.

Leino, Pentti - Helasvuo, MarjaLiisa - Lauerma, Petri - Nikanne, Urpo - Oniki Tima (toim.) 1990: Suomen kielen paikallissijat konseptuaalisessa semantiikassa. Kieli 5. Helsinki: Helsingin yliopiston suomen kielen laitos.

McCarthy, John J. 1982: Nonlinear pho- nology. An overview. - GLOW Newsletter 50. https://scholarworks.umass.edu/ linguist_faculty_pubs/50 (30.12.2019).

NiKanne, UrPo 1989: Keskustelua autonomisesta syntaksista ja formaalista kieliopista. - Jan-Ola Östman, Urpo Nikanne, Kristiina Jokinen \& Tapani Kelomäki (toim.), Suomen kielitieteellisen yhdistyksen vuosikirja 1989 s. 13-30. Helsinki: Suomen kielitieteellinen yhdistys.

- 1990: Zones and tiers. A study of thematic structure. Studia Fennica Linguistica 35. Helsinki: Suomalaisen Kirjallisuuden Seura.

— 1992: Kielentutkimus ja moraali. - Virittäjä 96 s. 419-426.

_ 1997: Suomen infiniittisten adjunktien temporaalinen tulkinta. - Virittäjä $101 \mathrm{~s}$. 338-357.

Paulsen, Geda 2011: Causation and dominance. A study of Finnish causative verbs expressing social dominance. Åbo: Åbo Akademi University Press.

Paunonen, Heik ki 1976: Allomorfien dynamiikkaa. - Virittäjä 8o s. 82-107.

Petrova, Окsana 2011: Of pearls and pigs. A conceptual-semantic Tiernet approach to formal representation of structure and variation of phraseological units. Åbo: Åbo Akademi University Press.

Pörn, Michaela 2004: Suomen tunnekausatiiviverbit ja niiden lausemaiset täydennykset. Suomalaisen Kirjallisuuden Seuran Toimituksia 1009. Helsinki: Suomalaisen Kirjallisuuden Seura.

SAG, Ivan A. 2012: Sign-based construction grammar. An informal synopsis. - Hans C. Boas \& Ivan A. Sag (toim.), Signbased construction grammar s. 69-202. CSLI Lecture Notes 193. Stanford, CA: Center for the Study of Language and Information. 